\title{
MEDIATIZATION AND STRATEGIC APPROPRIATION: POLITICAL MOBILISATION THROUGH MEDIA
}

\author{
Narendra Kumar ${ }^{* 1} \bowtie$ \\ ${ }^{* 1}$ Research Scholar, CSSEIP/School of Social Sciences, Jawaharlal Nehru University, New Delhi, \\ India
}

DOI: https://doi.org/10.29121/granthaalayah.v8.i6.2020.212

Article Type: Research Article

Article Citation: Narendra Kumar. (2020). MEDIATIZATION AND STRATEGIC APPROPRIATION: POLITICAL MOBILISATION THROUGH MEDIA. International Journal of Research GRANTHAALAYAH, 8(6), 15-19. https://doi.org/10.29121/granthaa layah.v8.i6.2020.212

Received Date: 06 May 2020

Accepted Date: 20 June 2020

Keywords:

Media

Public Opinion

Politicisation of Religion

Ideologically Constructed

\begin{abstract}
It is a well-known fact that the media plays a very crucial role in framing public opinion and it can influence the decision-making process as well as the future of a country. Despite being divided on the lines of caste, religion and language India is lagging its diversity in newsrooms all over the country. The essence of religion has been changed with space and time and through modern influences. Religion plays an important role in the lives of people. So, how religion becomes politicized concept? In other words, how to understand politicization of religion? The essence of religion varies from time to time, depends on the influence of political circumstances. Religion is a powerful phenomenon which is ideologically constructed and institutionalized for social domination. The main concern is that how the relationship between religion and politics is reflected through the media.
\end{abstract}

\section{INTRODUCTION}

Religion is the most powerful and influential force in human society. It influences all the institutions of society such as political, economic, and family etc. It has shaped the people's relationship with each other and is also responsible for human actions. Religious groups organize their collective religious expression. Religion plays an important role in a person's private and social life. It has the power to influence people's ideology, practicality and emotionality. It is kind of powerful tool which is particularly used for political gain such as power and position in political set up. Furthermore, politics has used religion, to institutionalized religion, to perpetuate ruling class ideologies, to justify their beliefs. Hence political parties majorly depend upon religious sentiments for their own profits. Likewise, Marx says that the function of religion is to legitimize structures of social domination. The relationship between religion and politics is not new. These two areas are segregated yet it is important to understand the appropriate relation between two. We can compare politics and religion to "this worldly and otherworldly" because on the one hand religions speak of other worldly concerns such as life, death etc. On the other hand politics majorly concerned with daily life and deals with power and positions. Religion identity plays an important role because it is helpful in political gain and sometimes gives birth to religio-nationalism. So, this culture 
religious identity helps political leaders in terms of support. Religion identity is simply effective in public sphere because through social interaction these religious practices, values and beliefs transmit to each other.

Arvind Rajagopal shows that the use of the cinema is responsible to blend historical facts with Hindutava mythology and create a kind of theological realism (Udupa p.13). The Indian televisions try to show the Hindu epic in serial form like Ramayana. The widely watched epic serial of Ramayana on Doordarshan created a 'mythic idea of history... whose precise status as fact or fiction was not relevant' (2007: 211). As, the depiction of the status of narratives on television never be clear whether fact or fiction. In the same way Jean Baudrillard says, that the original version lost behind the media narratives. Media always express their constructed ideologies in the language of choice and freedom. Political parties try to spread the communal feelings so that they win the elections and come to power. To take the example of research conducted by Indian social institute that, Hindutava ideology is basically constructed by BJP. They are uniting all the Hindus in the name of "Ram" by manipulating communal feelings along with its organizations such as, RSS, Bajrang Dal, and VHP etc. To misuse religious sentiments for political gain is dangerous for democracy. Furthermore, media plays a powerful role as it is a fourth pillar of democracy, but we need to look at that media is economic institute and always in the favor of ruling government for its own survival and profit. I would also like to show how the series of serials, movies and news promoting Hindutva ideology and politicize the religion. How these ideologies influence the individuals by promoting a unity as a sense of nationhood among Hindus which results into the emergence of Hindu Nationalism.

Different political parties have different ideologies and they target different religious communities for their vote banks. Hence they emerge as champions of their own communities but they are champions of their political interests rather than their community's interest. It is important to examine how civic nationalism degenerated into ethnic nationalism and to theorize a reason that why a particular ethnic identity has a tendency for mass appeal and politicization (Bose, 2009; p.7). There are few reasons point out by Bose that politicization of religion in India is firstly, the result of the anxiety of dominant Hindu groups towards several policies for minorities and lower caste Hindus. These dominant communities feel most threatened by these policies. Secondly, through manipulation of the mass media for religious ends. Thirdly, state policies also produce ethnic consciousness (Bose, 2009; p. 18). Hindu nationalism is simply a conservative ideology which aims to preserve the privileges of existing elite groups. Furthermore, Hindu nationalists were inspired by European fascism and majorly concerned with modernization and industrialization (Swamy, p.76).

In a country like India which is heterogeneous in terms of ethno-linguistic, ethnic identities simply represents as a powerful instrument for influencing voter's behavior. These identity based appeal is more effective in increasing the salience of those ethnic identity. Furthermore, the politico-religious campaign within India has been occurred in 1991 national elections. The main purpose of which was to increase of Hindu sentiments in the general population. Media framing influence political outcomes.

In recent census it is said that Hindu religion is divided into different castes and sub-castes. So, how to bring these diverse and pluralistic belief systems in single platforms? So, it is necessary to understand society on the basis of democratic sphere. So, the uniform organizations such as RSS, VHP etc try to politicize of Hindu religion through the aspect of nationalism for religious and political benefits. These organizations like RSS views themselves as cultural organization not political party. They have applied several methods to unify Hindus such as by building of temple at Ayodhya. There were more reasons by which the rise of Hindu nationalist occurred such as BJP, by making Hindi as a national language and by broadcasting the televised serials which depicts the Hindu epics to create a sense of shared cultural identity among Hindus.

\section{Mediatized Hindutva: Ideological State Apparatus}

During 1980's and 1990's the Hindu nationalist project is strongly linked to the mass media such as television. Media tries to promote religious nationalism likewise Stanley Tambiah asserts that "mass politics and mass religious fervor in many places now make efficacious and explosive use of communication media and high-tech devices. Aside from radio and films, followed by television, perhaps the most sensational recent development is the use of VCRs and audiocassettes, by means of which both villagers in remote rural areas and the unlettered in cramped urban slums can hear messages and see visual images propagated by leaders and ideologues from metropolitan centers".

Sunil khilnani states that "For many in India, modernity has been adopted through the conservative filters of religious piety, moralism, and domestic virtue. This has spawned a novel Hinduism, where holographic gods dangle 


\section{Narendra Kumar}

on well-used key chains and cassettes of devotional ragas are played in traffic jams." In India, people are against modern values or they use modern values to a particular extent because of their cultural integrity, traditional values and religious duties. Furthermore, the important point to notice is that mass media was fundamental to the spreading of religious nationalist ideology to far-flung villages and towns in all over the country. Thus, the process modernization did not successfully crush the role of religion instead this modernization process proved to be an essential vehicle for the expansion of Hindu Nationalism. Hindu national movement is limited to certain elite groups.

In recent times there are numerous online practices/activities done by self declared "internet Hindus" which are prominent, they constitute the group of right wing Hindu nationalist in India. These "internet Hindus" are active in gathering texts and arguments which simply portray the ideas of Hinduism and they share them aggressively into online media such as twitter, facebook, youtube etc. They are more excited to share, store, and trace these information and debates on Hindu mythologies, Hindu cultures, Hindu deities and Hindu kingdoms. These are considered as a new form of political agency that emerges along with social media. Furthermore, such practices are also responsible for producing religious differences and conflict within the country and also not good for democratic environment. The main aim of this online archiving by Hindu nationalist volunteers is to develop a sense of belongingness among religious political communities. This is an important online practice for religious nationalism. Contemporary media tries to show how different religions expressed and experience different forms of popular religiosity.

The role of the media in people's religious identity has grown. But, the most importantly context is important in which these both issues are located i.e. media and religion. If we talk about the relationship between media and religion, then, we simply need to divide media into two distinct categories. First is traditional media and second is modern media. In contemporary period the main concern is towards religion and modern media. It simply claimed the question of religion and modernization in the traditional world. The traditional world which is being faced by the modern world but its identity has been confused and in contrast with western "otherness". So, the complete transmission of traditional world into modern world cannot be possible. When traditional encounters with modern world there are no concrete patterns and hence perplexed, as well as when traditional world face materialized modernization they essentially make their relationship with that (H. Khojaste, A. Kalantari, 2009; p.287). The best suitable example of a traditional world is India which is a traditional one in terms of its culture, religious values, practices etc and simultaneously it encounters with modern media. The nature of media in the modern world is different from that of the traditional world. If we move towards looking up at the media institutions in modern world the results found different because through the emergence of modern media there was declining in religious institutions, social and private life. Hence, this results into the rise of the power of media and the decline of the importance of religion (H. Khojaste, A. Kalantari, 2009; p.290). Hence, some thinkers have pointed out that there should be some limitations on modern media. Furthermore, some steps have been taken to produce religious programs through establishing religious media in modern world. So, people in recent decades have used radios and televisions to revive religion. On the other hand traditional media were always helpful in spreading and stabilizing religious culture.

Media tries to compete with the concepts derived by religious institutions by creating general concepts of rituals and rites (Horsfield, 2003:222). So, when certain religious customs were spreading and stabilizing by the media itself in the society it is termed as religious media rituals which is distinct from non-religious rituals, that emerged by negative effects of modernization in western countries. These media rituals (religious and non-religious) are publicized by modern media such as through television and radio.

\section{MEDIA AND STRATEGIC FOCALISATION}

Furthermore, social media is also responsible for the construction of identities and the sites like facebook and twitter suggest a form of self identity. The main concern of facebook and twitter is that a person's individual opinion matters or taken into account. The relation of social media and Hindutva is changing the 'role of the public sphere' in the Indian society. The category of youth is dominating on social media with different perspectives. Fractured Consciousness absorbs the minds of the youth, with their participation on social media. The scenario of digital expansion reports the idea of expansion of distortion. In their study Yral Report 20161 found that at least 136 million Indians are active users on social media. According to a world bank report (2016), with around 30\% penetration of the internet, in India, the facebook users approximately more than 241 million have already there (The next web 
Mediatization And Strategic Appropriation: Political Mobilisation Through Media

report,2017). On the other side the penetration of whatsapp has increased with approximately 200 million users. It shows that social media is emerging like a sphere where the role of agency is changing.

The main reason for the construction of such identities is not for artistic purpose but for commercial reason. Anthony Giddens argues that the concept of Facebook and Twitter ensures self reflexivity and the ability to construct and develop one's own biographical narrative or identity. Social media is a democratic space and democracy wants the active participation of citizens. Social media is a space where anyone can share their views, opinions and ideologies. Social media is helpful and play an important role in deepening of democracy. People have freedom of speech and expression in different forms through modern media. Hence, social media has reinforced values and ideologies. It is also helpful to build peace and social consensus. Media can play a positive role in democracy but it totally depends on enabling environment that allows them to do so and if it is free from the media owner and the state. But media can also be responsible for withering away the democracy by playing anti-democratic roles through violence and division. Amartya Sen sees the media as a watchdog of the government functionaries and states that "A free press and the practice of democracy contribute greatly to bringing out information that can have an enormous impact on policies for famine prevention... a free press and an active political opposition constitute the best earlywarning system a country threatened by famine could have."

Furthermore, it is important to provide relevant information by media to different sections of the society on particular issues especially to the poor section. Otherwise they won't be able to aware about their rights and without the inclusion of poor people in the public sphere, democratic roots won't be possible. Likewise, for Habermas, Reliable information is an important constituent of any democratic society. Media considered as fourth estate in democracy. It provides the space for alternative ideas for debate and discussions. It plays an important role in the formation of public sphere.

In India public service broadcasting has given much importance after independence to bring several changes within society. AIR (All India Radio) and Doordarshan had the major responsibility of to provide education programs along with information and entertainment as first public service broadcasters within the country. Furthermore, it is important to notice that the public service broadcasting system is closely associated or identified with the state in the country. In other simple words press is not free from the state. Media institutions come under the control of the state hence; they represent the news and events according to the ruling government ideology as media is majorly an economical and political organization. Another problem within the field of media is about ownership. Such as, with the emergence of a competitive market in the field of media, the public service broadcasters had been challenged by private entities. Hence, it results in the media become more economic entity rather than democratic institution. So, media should monitor on professional ethical standards because it is accountable to general population.

\section{CONCLUSION}

All type's social media involve the practice of developing Hindutava ideology such as through facebook, twitter, blogs, posts etc. The positive aspect of this social media is that people can express their opinions, views and ideologies through this modern media. Simultaneously, it is important to notice that a particular type of ideology is developing, which is dangerous for democratic growth of society because the other groups and minorities are simply being avoided by social media. I would like to conclude this paper by giving certain examples from contemporary media in India. My major concern in this paper is generally on social media but here I am particularly focusing on televisions. In contemporary times the Hindutva ideology simply reflects through the series of serials such as series of Ramayana and Mahabharta, Devyanshi, Shani, Nagin these entire serials simply depicts the Hindu culture, ideology and mythology to revive Hindu religion. There is a need to understand these series of serials deeply. These series are not simply for the audience or according to the taste of the viewers but the great politics involved within it. It is important to notice that how media tries to politicize the religion. How media tries to influence the general population by reinforcing these Hindutava ideologies. Hence, media portrays news and events according to the taste of ruling government for its own survival and profit. They not merely provide limited information related to particular ideology but they are also responsible for the production and reproduction of those ideologies. The concept of politicization of religion requires deep understanding and observation. The relationship between media, politics and religion cannot be easily understandable. 


\section{SOURCES OF FUNDING}

None.

\section{CONFLICT OF INTEREST}

None.

\section{ACKNOWLEDGMENT}

None.

\section{REFERENCES}

[1] Bose, A. Hindutva and the Politicization of Religious Identity in India. Journal of Peace, Conflict and Development, 2009, 1-30.

[2] Coronel, S. S. The Role of the Media in Deepening Democracy, (https://doksi.net/get.php?) 2003, 1-23.

[3] Dutta, S. Social Responsibility of Media and Indian Democracy. Global Media Journal, 2011, 1-8.

[4] Horsfield, P. J. (2003). "Development of Religion in the Age of Media", in Hoover, Stewart M. and Lundby, Knut Open-mindedness in Media, Religion and Culture. Translated by: Mas'oud Armenia. Soroosh, 2003.

[5] Khilnani, S. The idea of India. London: Penguin Books, 2003.

[6] Khojaste, H., \& Kalantari, A. The Relationship between Media and Religion. Asian Journal of Social Science, 2009, 284-304.

[7] Rajagopal, A. Politics after television: Religious nationalism and the reshaping of the Indian public. UK: Cambridge University Press, 2001.

[8] Rajagopal, A. The Gujarat experiment and Hindu national realism: Lessons for secularism in A. Needham and R. Sunder Rajan (Eds.), The crisis of secularism in India. Duke university Press, 2007, 208-224.

[9] SJ*, M. D., \& SJ**, A. F. (n.d.). Politicization of Religious Identity: A Case of Mangalore.

[10] Swamy, A. R. Ideology, Organization and Electoral Strategy of Hindu Nationalism: What's Religion Got to Do with It?, 2003, 73-100.

[11] Tambiah, S. Levelling Crowds: Ethnonationalsit conflicts and collective violence in South Asia. Berkeley: University of California Press, 1996.

[12] Udupa, S. Online Archiving as Claims to History: New Media and Religious Politics in India. MMG Working Paper, 2014, 14-10, 1-30.

[13] https://www.livemint.com/Opinion/ZAHBp4YDLp1BcCnlIuwFON/Hate-speech-and-the-role-of-social-medi a.html 